
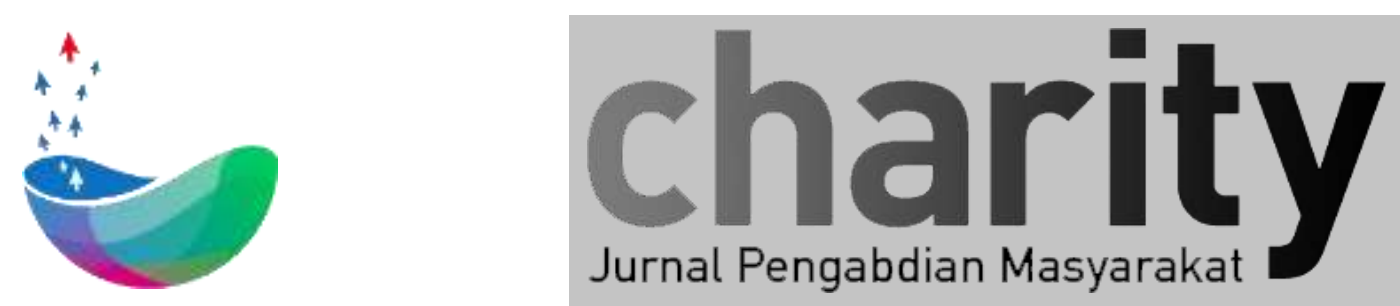

\title{
IPTEK BAGI MASYARAKAT FORUM KOMUNIKASI UKM KECAMATAN DRAMAGA KABUPATEN BOGOR
}

\author{
Suyanto ${ }^{1}$, Satria Mandala ${ }^{2}$, Wiyono Sutari ${ }^{3}$, Rino Andias Anugraha ${ }^{4}$, Budi Santosa ${ }^{5}$, Agus Alex Yanuar ${ }^{6}$ \\ 'Fakultas Informatika, Universitas Telkom \\ ${ }^{2}$ Fakultas Informatika, Universitas Telkom \\ Fakultas Rekayasa Industri, Universitas Telkom \\ Fakultas Rekayasa Industri, Universitas Telkom \\ Fakultas Rekayasa Industri, Universitas Telkom \\ ${ }^{6}$ Fakultas Rekayasa Industri, Universitas Telkom \\ suyanto@telkomuniversity.ac.id, satriamandala@telkomuniversity.ac.id, wiyono@telkomuniversity.ac.id, rinoandias@telkomuniversity.ac.id, \\ budisantosa@telkomuniversity.ac.id, axytifri@telkomuniversity.ac.id
}

\section{INFO ARTIKEL}

Diterima 01 Februari 2019

Direvisi 08 Februari 2019

Disetujui 30 Agustus 2019

Tersedia Online 09 September 2019

\begin{abstract}
ABSTRAK
Pada tahun 2013, beberapa pemilik Usaha Kecil dan Menengah (UKM) Kabupaten Bogor, didukung oleh Dekranasda, Dinas Koperasi dan UMKM serta Dinas Perindustrian dan Perdagangan Kabupaten Bogor, mendirikan sebuah Forum Komunikasi UKM (FKUKM). Forum ini diharapkan dapat membantu para pemilik UKM di Kabupaten Bogor dalam menyelesaikan masalah usaha mereka. Sebagai salah satu pelaku usaha di Indonesia, UKM tak bisa menghindari dampak persaingan global. Ketika jarak menyempit dan pemasaran kian luas cakupannya, beberapa UKM di daerah masih belum dapat menikmati hal ini karena kurangnya pengetahuan. Produksi usaha yang beragam dan berkualitas, belum dapat dipasarkan secara online dan hanya bisa dirasakan oleh masyarakat di lingkungan sekitar. Akibatnya, omset pun tak bisa optimal. Untuk membantu para anggota FKUKM, pada kegiatan abdimas ini dibangun sebuah e-commerce platform untuk pemasaran online produk anggota FKUKM. Selain itu juga dilakukan pelatihan aplikasi e-commerce dan mobile photography bagi anggota FKUKM.
\end{abstract}

Keyword: aplikasi e-commerce, iptek bagi masyarakat, pelatihan mobile photography

Korespondensi:

Direktorat Penelitian dan Pengabdian Masyarakat, Universitas Telkom

Jl. Telekomunikasi No. 1, Terusan Buah Batu, Bandung, 40257 Indonesia

E-mail : charity@telkomuniversity.ac.id

ORCID ID: 0000-0002-8897-8091

Penulis Pertama: Suyanto

https://doi.org/10.25124/charity.v2i1.1827

Paper_reg_number 1827 (C) The Authors. Published by Directorate of Research and Community Service, Telkom University.

This is an open access article under the CC BY-NC 4.0 license (https:/creativecommons.org/licenses/ by-nc/4.0/) 


\section{Pendahuluan}

Di awal September 2015, pemerintah menerbitkan kebijakan fiskal yang mendorong perekonomian nasional. Salah satu poin kebijakan tersebut ditujukan pada pemberdayaan Usaha Mikro, Kecil dan Menengah (UMKM) [1]. Mengapa hal ini dilakukan? Sebab UMKM terbukti sebagai salah satu sektor strategis dalam perekonomian nasional yang tercermin dari besarnya serapan tenaga kerja [2], [3], [4]. Selain itu, UMKM juga terbukti tahan terhadap krisis moneter [5].

Data Badan Pusat Statistik (BPS) tahun 2012 menyebutkan jumlah tenaga kerja UMKM sejumlah 107,6 juta pekerja atau 97\% dari total tenaga kerja Indonesia [6]. Sebagian besar serapan tenaga kerja tersebut berada pada usaha mikro yaitu $90 \%$, sedangkan usaha kecil $4 \%$ dan sisanya sejumlah $3 \%$ adalah tenaga kerja di sektor usaha menengah. Kriteria UMKM Berdasarkan Undang-Undang Nomor 20 Tahun 2008 Tentang UMKM diilustrasikan pada Tabel 1.

Tabel 1. Kriteria UMKM Berdasarkan Undang-Undang Nomor 20 Tahun 2008

\begin{tabular}{|r|r|r|}
\hline Pelaku Usaha & ${\text { Kekayaan Bersih }(\mathbf{R p})^{\mathbf{1}}}$ & Hasil Penjualan Tahunan (Rp) $^{-}$Sampai dengan 300.000 .000 \\
\hline Usaha Mikro & Sampai dengan 50.000.000 & Sa \\
\hline Usaha Kecil & $50.000 .000-500.000 .000$ & $300.000 .000-2.500 .000 .000$ \\
\hline Usaha Menengah & $500.000 .000-10.000 .000 .000$ & $2.500 .000 .000-50.000 .000 .000$ \\
\hline
\end{tabular}

Keterangan: ${ }^{1)}$ Hasil pengurangan total nilai kekayaan usaha dengan total nilai kewajiban, tidak termasuk tanah dan bangunan tempat usaha.

Sementara itu, data statistik tentang jumlah unit UMKM mendekati 99,98\% terhadap total unit usaha di Indonesia. Artinya, jika jumlah unit tersebut ditingkatkan maka diprediksi akan semakin banyak tenaga kerja yang diperlukan. Dengan demikian, nilai pengangguran pun diharapkan akan menurun. Satu berita menarik dari Indopremier menyebutkan bahwa pada tahun 2019 sektor UMKM diprediksi tumbuh lebih baik [7].

Namun, di sisi lain UMKM sendiri masih menghadapi tantangan yang cukup besar dalam pengembangannya. Berbagai permasalahan seperti kurangnya akses permodalan, teknologi informasi, pemasaran dan produksi masih menghantui UMKM. Menurut I Wayan Dipta, Deputi Bidang Produksi Kementerian Koperasi dan UKM, sejumlah 67,8\% modal yang dimiliki oleh UMKM diperolah dari pemilik usaha yang bersangkutan.

Belum lagi persoalan teknologi informasi, yang cenderung dikuasai oleh generasi muda di kota besar. Sedangkan pelaku UMKM bukan hanya berada di kota besar melainkan juga di daerah-daerah.

Atas dasar keinginan yang sama untuk memajukan usaha masing-masing inilah maka para pemilik UMKM di Kabupaten Bogor membentuk forum komunikasi yang mereka namakan Forum Komunikasi UKM Kabupaten Bogor. Forum ini didukung penuh oleh pemerintah Kabupaten Bogor dan dinas terkait. Dan pada bulan Februari 2016, Kecamatan Dramaga yang merupakan salah satu kecamatan di Kabupaten Bogor, turut mendirikan forum yang sama di wilayah mereka. 
Forum Komunikasi UKM Kecamatan Dramaga Kabupaten Bogor bertujuan untuk:

1. Saling berbagi atas permasalahan yang dihadapi sehingga lebih mudah menemukan solusi.

2. Maju bersama dalam persaingan yang sehat.

3. Meningkatkan omset melalui peningkatan promosi bersama

4. Berbagi ilmu sehingga masing-masing anggota dapat meningkatkan pengetahuan dan wawasan kewirausahaan.

Forum Komunikasi UKM Kecamatan Dramaga bekerja di bawah koordinasi forum yang sama di tingkat kabupaten. Salah satu produk unggulannya adalah berbagai olahan dari buah pala, seperti gula-gula, sirup dan keripik. Gambar 1 di atas adalah foto pengurus Forum Komunikasi UKM Kecamatan Dramaga dengan berbagai produk unggulannya yang terbuat dari berbagai macam bahan. Sayangnya, produk unggulan ini belum bisa dipasarkan lebih luas karena kurangnya pengetahuan tentang e-commerce. Pesatnya perkembangan teknologi yang tak lagi dapat dibendung membuat para pengurus yang diketuai oleh Ibu Wida ini berkeinginan untuk menambah pengetahuan di bidang teknologi informasi.

Untuk itu, kerjasama dengan kami dilakukan dengan prosedur pengabdian masyarakat untuk pembuatan website e-commerce yang digunakan untuk promosi, pemasaran dan transaksi online serta pelatihan e-commerce.

Dari hasil diskusi dengan mitra, bantuan di bidang teknologi informasi ini diharapkan akan meningkatkan kemampuan bisnis para pengurus yang kemudian akan ditularkan kepada seluruh anggota, perluasan pangsa pasar dan peningkatan omset setiap anggota.

\subsection{Permasalahan Mitra dan Tujuan Kegiatan}

Dari penjabaran analisis situasi, dapat dilihat bahwa masalah yang dihadapi para anggota forum yang notabene para pemilik UKM adalah terbatasnya pemasaran akibat terbatasnya pengetahuan akan teknologi informasi seperti tidak adanya website yang dapat menampung informasi produk, kurangnya pengetahuan tentang pemasaran online sehingga tidak dapat melakukan promosi dan transaksi online. Dua masalah ini diakui oleh mitra sebagai masalah krusial yang harus segera dicarikan solusi.

Setelah website e-commerce forum dibangun dan para pengurus memahami operasionalnya, diharapkan usaha masing-masing anggota akan semakin meningkat, ditandai dengan peningkatan omset. Gambar 2 di bawah ini adalah gambaran umum peta masalah pemasaran hasil UKM. 


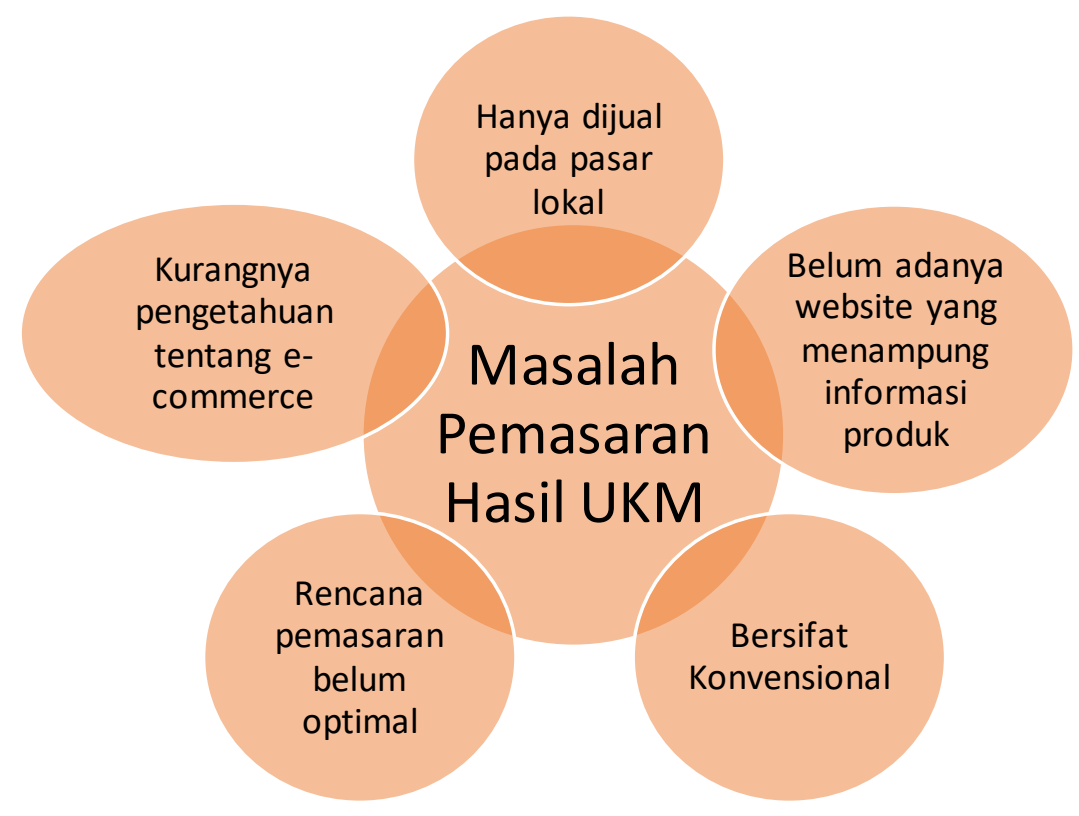

Gambar 1. Peta Masalah Pemasaran

\subsection{Potensi Pemberdayaan Masyarakat}

Kegiatan pengabdian masyarakat ini secara langsung melibatkan forum komunikasi usaha kecil menengah di Kecamatan Dramaga, Kabupaten Bogor. Setelah kegiatan ini, diharapkan forum komunikasi yang dimaksud memiliki sarana komunikasi berbasis teknologi informasi yang efektif, sehingga dapat meningkatkan kegiatan perekonomian yang dilakukan.

\subsection{Solusi yang Diusulkan}

Seperti yang telah diungkapkan pada permasalahan Mitra, solusi yang diusulkan adalah dengan pembuatan website e-commerce dilanjutkan dengan pelatihan cara penggunaannya. Solusi yang ditawarkan ini adalah sebagai berikut:

1) Pembuatan sebuah website e-commerce (termasuk biaya hosting selama setahun) yang menarik dan aman untuk kepentingan pemasaran hasil UKM.

2) Peserta pelatihan adalah seluruh pengurus Forum Komunikasi UKM Kecamatan Dramaga, Kabupaten Bogor untuk selanjutnya secara estafet ditularkan kepada semua anggota yang menghendaki.

3) Modul pelatihan memuat semua materi pelatihan beserta contoh prakteknya.

\section{Metode Pelaksanaan Pengabdian Masyarakat}

\subsection{Bentuk dan Tahap Kegiatan}

Berdasarkan permasalahan mitra yang berkaitan dengan pemasaran hasil UKM, kami menawarkan solusi berupa pembuatan website e-commerce yang menarik dan aman untuk kepentingan pemasaran online dilanjutkan dengan pelatihan e-commerce bagi pengurus Forum Komunikasi UKM Kecamatan Dramaga, Kabupaten Bogor. 
Target dan luaran dari solusi yang ditawarkan ini adalah penerapan teknologi untuk pemasaran hasil karya UKM yaitu adanya website dilengkapi dengan peningkatan kapasitas pengurus Forum Komunikasi sehingga memiliki pengetahuan dan kemampuan untuk memanfaatkan website secara optimal dalam pemasaran online.

Selain itu juga akan diberikan modul yang dibuat oleh tim pelaksana. Modul berisi semua materi pelatihan dan latihan-latihannya ini dapat dimanfaatkan oleh pengurus untuk menularkan ilmu yang mereka peroleh kepada anggota Forum Komunikasi. Luaran lainnya juga berupa pemberian sertifikat bagi pelaksana dan peserta pelatihan. Sertifikat akan ditandatangani oleh ketua pelaksana dan Direktur PPM Universitas Telkom.

\subsection{Partisipasi Mitra}

Mitra langsung dalam kegiatan pengabdian masyarakat ini adalah anggota dari Forum Komunikasi Usaha Kecil dan Menengah (UKM) Kecamatan Dramaga Kabupaten Bogor. Mitra bertugas untuk:

a. Menyiapkan peserta kegiatan pelatihan.

b. Memberikan evaluasi dan feedback terhadap kegiatan pelatihan

\subsection{Evaluasi dan Keberlanjutan}

Pelaksanaan kegiatan pengabdian masyarakat ini dilakukan secara kontinu dalam waktu delapan bulan, mulai dari survei, pembangunan website ecommerce hingga pelatihan penggunaan dan pengembangan konten web. Mitra berperan sebagai sumber informasi dalam pembuatan website ecommerce sehingga tersaji sebuah website yang menarik. Selain itu, mitra, dalam hal ini pengurus Forum Komunikasi juga berperan sebagai peserta pelatihan.

Setelah adanya website e-commerce dan pelatihan penggunaan serta pengembangan konten web, mitra diharapkan dapat secara mandiri mengembangkan konten website yang lebih menarik sesuai dengan kebutuhan mereka. Hal ini diukur dengan cara melakukan jajak pendapat melalui kuesioner.

\section{Analisis Hasil Pelaksanaan Kegiatan Pengabdian Masyarakat}

\subsection{Bentuk dan Tahap Kegiatan}

Bentuk kegiatan berupa pembangunan dan pelatihan aplikasi e-commerce. Pembangunan aplikasi e-commerce dilaksanakan di Fakultas Informatika Universitas Telkom selama bulan Juni sampai November 2018. Sementara itu, pelatihan aplikasi e-commerce dilaksanakan di kantor FKUKM Kec. Dramaga, Kab. Bogor pada akhir bulan November 2018.

\subsection{Feedback Kegiatan}

Pada kegiatan ini dilakukan jajak pendapat melalui kuesioner dengan hasil seperti pada Tabel 2. Pihak mitra berharap TelU bersedia memberikan 
pendampingan selama dua atau tiga tahun ke depan sebagai pengelola konten dan data center hingga forum mampu melakukan swakelola aplikasi $e$ commerce SerbaLokal.

Tabel 2. Kuesioner aplikasi SerbaLokal dan Pelatihan Mobile Photography

\begin{tabular}{|c|l|c|c|c|c|c|}
\hline N & \multicolumn{1}{|c|}{ Pertanyaan } & \multicolumn{5}{|c|}{ Nilai } \\
& \multicolumn{1}{|c|}{} & 1 & 2 & 3 & 4 & 5 \\
\hline 1 & Aplikasi SerbaLokal responsif & & & & 1 & 1 \\
\hline 2 & Aplikasi SerbaLokal mudah digunakan & & & & 2 & \\
\hline 3 & $\begin{array}{l}\text { Menu pada Aplikasi SerbaLokal sudah bekerja } \\
\text { sebagaimana mestinya }\end{array}$ & & 1 & & 1 & \\
\hline 4 & $\begin{array}{l}\text { Pengaksesan pada aplikasi SerbaLokal sangat } \\
\text { sepat }\end{array}$ & & & 1 & 1 & \\
\hline 5 & Aplikasi SerbaLokal sempat mengalami error & 1 & & & 1 & \\
\hline 6 & $\begin{array}{l}\text { Anda tidak kebingungan saat pertama kali } \\
\text { menggunakan aplikasi SerbaLokal }\end{array}$ & & 1 & 1 & & \\
\hline 7 & $\begin{array}{l}\text { Materi Pelatihan yang diberikan sangat sesuai } \\
\text { dan relevan }\end{array}$ & & & & 4 & 3 \\
\hline 8 & Pembicara menjawab pertanyaan dengan baik & & & 1 & 1 & 6 \\
\hline 9 & $\begin{array}{l}\text { Pembicara menjawab pertanyaan dengan } \\
\text { sangat akurat }\end{array}$ & & & 1 & 3 & 5 \\
\hline 10 & $\begin{array}{l}\text { Pelatihan yang diberikan sesuai dengan yang } \\
\text { diharapkan }\end{array}$ & & & 1 & 3 & 5 \\
\hline 11 & $\begin{array}{l}\text { Penyampaian materi dari pembicara sangat } \\
\text { mudah dimengerti }\end{array}$ & & & 5 & 4 \\
\hline & Masukan: & & & & & \\
\hline & Saran: & & & & & \\
\hline
\end{tabular}

\section{Keterangan Penilaian:}

\begin{tabular}{|c|c|}
\hline 1 & Tidak Setuju \\
\hline 2 & Kurang Setuju \\
\hline 3 & Netral \\
\hline 4 & Setuju \\
\hline 5 & Sangat Setuju \\
\hline
\end{tabular}

Dalam pelatihan penggunaan aplikasi e-commerce SerbaLokal, para peserta pelatihan mampu mengoperasikan fitur sebagai Seller. Mereka dapat menambahkan produk baru, menuliskan spesifikasi produk secara detail, dan mengunggah foto-foto produk baru tersebut. Mereka juga dapat mengoperasikan fitur sebagai Buyer, yaitu memilih dan membeli produk dan mengikuti alur proses hingga transaksi selesai dan produk dikirim ke alamat tujuan.

Selanjutnya, di sesi kedua dalam pelatihan mobile photography, para peserta antusias menyiapkan peralatan fotografi yang berupa mini studio dan lampu meja sederhana. Mereka mengikuti pelatihan secara serius dengan banyak pertanyaan mendasar hingga mereka mampu mengoperasikan kamera handphone untuk memotret produk-produk mereka. Hasil pemotretan produk 
tersebut mereka unggah langsung ke akun aplikasi e-commerce SerbaLokal sebagai Seller. Dengan demikian, kedua pelatihan saling berkaitan tersebut secara langsung membangun keterampilan mereka dalam menjalankan aplikasi e-commerce SerbaLokal.

\subsection{Tinjauan Hasil}

Untuk sementara, aplikasi e-commerce diberi nama SerbaLokal. Rencananya pihak mitra akan memberikan nama yang lebih sesuai berdasarkan kesepakatan forum. Dalam pelatihan penggunaan aplikasi $e$ commerce SerbaLokal, para peserta pelatihan sudah dapat mengoperasikan fitur sebagai Seller (menambah produk, dengan spesifikasi dan unggah foto produk) maupun Buyer (membeli produk hingga transaksi selesai). Dalam pelatihan mobile photography, para peserta pelatihan antusias mengikuti hingga mampu mengoperasikan kamera handphone untuk memotret produkproduk mereka yang hasilnya langsung mereka unggah ke akun aplikasi $e$ commerce SerbaLokal sebagai Seller. Kedua pelatihan tersebut sengaja didesain saling berkaitan untuk membangun keterampilan peserta dalam menjalankan aplikasi e-commerce SerbaLokal.

\section{Kesimpulan dan Saran}

Sebuah prototipe aplikasi e-commerce bernama SerbaLokal telah berhasil dibangun. Prototipe ini telah diuji coba di Forum UKM dalam sebuah pelatihan penggunaan aplikasi e-commerce SerbaLokal. Para anggota forum memberikan penilaian sebesar $85,18 \%$ setuju dan sangat setuju bahwa prototipe tersebut mudah digunakan. Dalam pelatihan mobile photography, para peserta pelatihan juga memberikan penilaian bahwa pemotretan produk menggunakan kamera handphone relative mudah dilakukan dengan hasil yang bagus.

\section{DAFTAR PUSTAKA}

[1] M. Z. Abidin, "Kebijakan Fiskal dan Peningkatan Peran Ekonomi UMKM," www.kemenkeu.go.id, 2015. [Online]. Available:

https://www.kemenkeu.go.id/media/4392/kebijakan-fiskal-dan-peningkatan-peranekonomi-umkm.pdf.

[2] A. A. Chandra, "UMKM Serap 57,9 Juta Tenaga Kerja," Detik-Finace, 2016. [Online]. Available: https://finance.detik.com/berita-ekonomi-bisnis/d3350243/umkm-serap-579-juta-tenaga-kerja.

[3] D. Murdaningsih, "UMKM Paling Banyak Serap Tenaga Kerja di Indonesia," Republika, 2018. [Online]. Available:

https://republika.co.id/berita/ekonomi/korporasi/18/10/11/pgf0ow368-umkm-palingbanyak-serap-tenaga-kerja-di-indonesia.

[4] N. Nurulliah, "Demiz Bakal Dorong Industri Hilir UMKM Agar Serap Tenaga Kerja Lebih Banyak," Pikiran Rakyat, 2018. [Online]. Available: https://www.pikiranrakyat.com/bandung-raya/2018/03/28/demiz-bakal-dorong-industri-hilir-umkm-agarserap-tenaga-kerja-lebih-banyak.

[5] K. M. Jannah, "Hebatnya UMKM, Tahan Krisis hingga Serap Banyak Pekerja," Okezone, 2016. [Online]. Available: 
https://economy.okezone.com/read/2016/01/25/320/1296249/hebatnya-umkm-tahankrisis-hingga-serap-banyak-pekerja.

[6] B. Indonesia and LIPI, "Profil bisnis usaha mikro, kecil dan menengah (UMKM)," 2015.

[7] Marjudin, "Sektor UMKM Diprediksi Akan Tumbuh Lebih Baik Tahun 2019," Indopremier, 2018. [Online]. Available:

https://www.indopremier.com/ipotnews/newsDetail.php?jdl=Sektor_UMKM_Dipredi ksi_Akan_Tumbuh_Lebih_Baik_Tahun_2019\&news_id=97725\&group_news=IPOT NEWS\&news_date=\&taging_subtype $=$ INDUSTRILAINNYA\&name $=\&$ search $=y \_g e$ neral\&q=UMKM, koperasi\&halaman $=1$. 